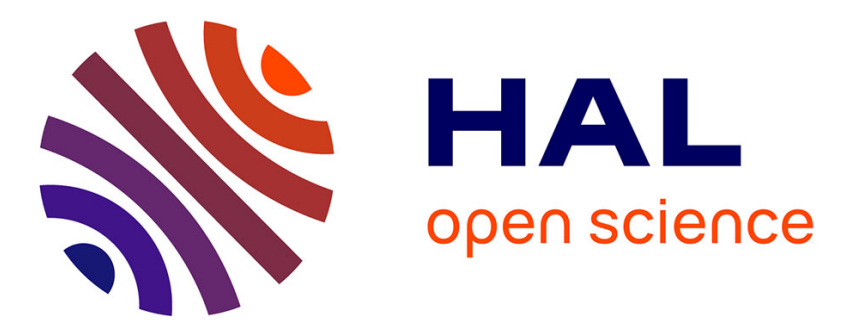

\title{
Combining objects with rules to represent aggregation knowledge in data warehouse and OLAP systems
}

Nicolas Prat, Isabelle Comyn-Wattiau, Jacky Akoka

\section{To cite this version:}

Nicolas Prat, Isabelle Comyn-Wattiau, Jacky Akoka. Combining objects with rules to represent aggregation knowledge in data warehouse and OLAP systems. [Research Report] DR 09014, ESSEC Business School, Document de Recherche ESSEC / ISSN : 1291-9616. 2009. hal-00551866

\section{HAL Id: hal-00551866 https://essec.hal.science/hal-00551866}

Submitted on 4 Jan 2011

HAL is a multi-disciplinary open access archive for the deposit and dissemination of scientific research documents, whether they are published or not. The documents may come from teaching and research institutions in France or abroad, or from public or private research centers.
L'archive ouverte pluridisciplinaire HAL, est destinée au dépôt et à la diffusion de documents scientifiques de niveau recherche, publiés ou non, émanant des établissements d'enseignement et de recherche français ou étrangers, des laboratoires publics ou privés. 


\section{CENTRE DE RECHERCHE}

Combining Objects with Rules to Represent Aggregation Knowledge in Data Warehouse AND OLAP SYSTEMS

Nicolas PRAT

ISABELLE COMYN-WATTIAU

JACKY AKOKA

DECEMBER 2009

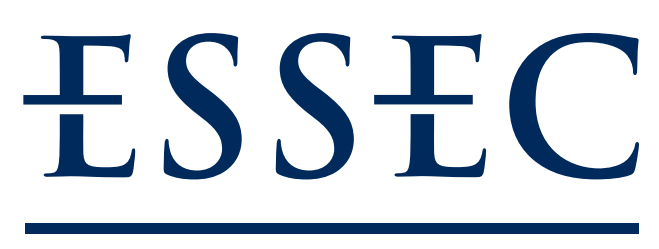

BUSINESS SCHOOL

PARIS-SINGAPORE 
Il est interdit de reproduire ce document ou d'en citer des extraits sans l'autorisation écrite des auteurs.

It is forbidden to quote all or part of this document without the written consent of the authors.

- DR 09014 -

\section{Combining Objects with Rules to Represent Aggregation Knowledge in Data Warehouse and OLAP Systems}

Nicolas PRAT, Isabelle COMYN-WATTIAU, Jacky AKOKA

December 2009 


\section{Combining Objects with Rules to Represent Aggregation Knowledge in Data Warehouse and OLAP Systems}

\section{ABSTRACT:}

Data warehouses are based on multidimensional modeling. Using On-Line Analytical Processing (OLAP) tools, decision makers navigate through and analyze multidimensional data. Typically, users need to analyze data at different aggregation levels (using roll-up and drill-down functions). Therefore, aggregation knowledge should be adequately represented in conceptual multidimensional models, and mapped in subsequent logical and physical models. However, current conceptual multidimensional models poorly represent aggregation knowledge, which (1) has a complex structure and dynamics and (2) is highly contextual. In order to account for the characteristics of this knowledge, we propose to represent it with objects (UML class diagrams) and rules in Production Rule Representation (PRR) language. Static aggregation knowledge is represented in the class diagrams, while rules represent the dynamics (i.e. how aggregation may be performed depending on context). We present the class diagrams, and a typology and examples of associated rules. We argue that this representation of aggregation knowledge allows an early modeling of user requirements in a data warehouse project.

\section{Key-Words:}

- Aggregation

- Conceptual Multidimensional Model

- Data Warehouse

- On-line Analytical Processing (OLAP)

- Production Rule

- UML

\section{RESUME :}

Les entrepôts de données reposent sur la modélisation multidimensionnelle. A l'aide d'outils OLAP, les décideurs analysent les données à différents niveaux d'agrégation. Il est donc nécessaire de représenter les connaissances d'agrégation dans les modèles conceptuels multidimensionnels, puis de les traduire dans les modèles logiques et physiques. Cependant, les modèles conceptuels multidimensionnels actuels représentent imparfaitement les connaissances d'agrégation, qui (1) ont une structure et une dynamique complexes et (2) sont fortement contextuelles. Afin de prendre en compte les caractéristiques de ces connaissances, nous proposons de les représenter avec des objets (diagrammes de classes UML) et des règles en langage PRR (Production Rule Representation). Les connaissances d'agrégation statiques sont représentées dans les digrammes de classes, tandis que les règles représentent la dynamique (c'est-à-dire comment l'agrégation peut être effectuée en fonction du contexte). Nous présentons les diagrammes de classes, ainsi qu'une typologie et des exemples de règles associées.

\section{Mots-clés :}

- Agrégation

- Entrepôt de données

- Modèle conceptuel multidimensionnel

- OLAP

- Règle de production

- UML

JEL classification : M15, C88 


\title{
Combining Objects with Rules to Represent Aggregation Knowledge in Data Warehouse and OLAP Systems
}

\author{
Nicolas Prat ${ }^{1}$, Isabelle Comyn-Wattiau², Jacky Akoka ${ }^{3}$ \\ ${ }^{1}$ ESSEC Business School, avenue Bernard Hirsch, BP 50105, 95021 CERGY Cedex, France \\ prat@essec.fr \\ ${ }^{2}$ CEDRIC-CNAM \& ESSEC Business School, 292 rue St Martin, 75141 PARIS \\ Cedex 03, France \\ wattiau@cnam.fr \\ ${ }^{3}$ CEDRIC-CNAM \& TMSP, 292 rue St Martin, 75141 PARIS Cedex 03, France \\ akoka@cnam.fr
}

\begin{abstract}
Data warehouses are based on multidimensional modeling. Using On-Line Analytical Processing (OLAP) tools, decision makers navigate through and analyze multidimensional data. Typically, users need to analyze data at different aggregation levels (using roll-up and drill-down functions). Therefore, aggregation knowledge should be adequately represented in conceptual multidimensional models, and mapped in subsequent logical and physical models. However, current conceptual multidimensional models poorly represent aggregation knowledge, which (1) has a complex structure and dynamics and (2) is highly contextual. In order to account for the characteristics of this knowledge, we propose to represent it with objects (UML class diagrams) and rules in Production Rule Representation (PRR) language. Static aggregation knowledge is represented in the class diagrams, while rules represent the dynamics (i.e. how aggregation may be performed depending on context). We present the class diagrams, and a typology and examples of associated rules. We argue that this representation of aggregation knowledge allows an early modeling of user requirements in a data warehouse project.
\end{abstract}

Keywords: Data warehouse, On-line Analytical Processing (OLAP), Conceptual multidimensional model, aggregation, UML, Production rule.

\section{Introduction}

Data warehouses are the cornerstone of data-driven decision support systems (DSS) [11]. They rely on a multidimensional model, providing users with a businessoriented view of data. Using On-Line Analytical Processing (OLAP) tools, decision makers may then navigate through and analyze multidimensional data. Typically, users need to analyze data at different aggregation levels, which is achieved by means of the roll-up operator (and its converse operator, the drill-down operator). Therefore, in order to ensure correct and flexible aggregation, aggregation knowledge should be 
adequately represented in conceptual multidimensional models, and mapped in subsequent logical and physical models. This aggregation knowledge pertains to aggregation functions that can be applied, as well as to hierarchies along which they are applicable, etc.

Several authors have studied how data may be aggregated along hierarchies (a.k.a. summarizability), and several conceptual multidimensional models incorporate aggregation knowledge [2,6,9,14]. [2] includes summarizability constraints. [5] develops a taxonomy of the additive nature of measures (non-, semi-, fully-additive). [9] introduces non-additivity and semi-additivity as constraints on measures. Based on the typology of aggregation functions presented in [13], [6] defines aggregations using 4 restriction levels. For example, level 3 only allows COUNT operations on measures. [4] uses intentional rules to define exceptions in aggregation hierarchies; this paper illustrates the applicability of rules to model aggregation knowledge, but does not consider aggregation functions. Finally, [7] defines three necessary conditions for summarizability: disjointness, completeness of category attributes, and temporal specific conditions.

Despite the contributions of previous research, aggregation knowledge is still poorly or inadequately represented in current conceptual multidimensional models. Aggregation knowledge is difficult to represent in a simple way [15]. This knowledge (1) has a complex structure and dynamics and (2) is highly contextual in nature (e.g. the aggregation functions that may be applied at a given time may depend on the functions applied previously). In order to account for the characteristics of aggregation knowledge, we propose to represent it with objects (UML class diagrams [12]) and rules (in Production Rule Representation language [12]). Static aggregation knowledge is represented in the UML class diagrams, combined with PRR rules which represent the dynamics (i.e. how aggregation may be performed depending on context).

The rest of the paper is organized as follows. Section 2 focuses on the representation of static aggregation knowledge, using UML class diagrams. Section 3 proposes a typology of rules to represent dynamic aggregation knowledge, and illustrates how these rules may be represented and organized in the PRR formalism. Section 4 concludes and points to further research.

\section{Representing Static Aggregation Knowledge: UML Class Diagrams}

A conceptual multidimensional model should clearly distinguish between structure (schema) and content (instances) [15]. In our approach, this distinction is crucial, since aggregations (roll-ups) will be performed at the instance level. We therefore distinguish between the core conceptual multidimensional model (used for the conceptual representation of a data warehouse), and the data cube model. A data cube is a user view on multidimensional data (like the core conceptual multidimensional model, the data cube model is represented at the conceptual level, i.e. independently of any OLAP implementation). Aggregations operate on and result in data cubes. 
The UML class diagram of Figure 1 represents the static view of the core conceptual multidimensional model. This model draw on earlier work $[3,14]$ and focuses more specifically on concepts related to aggregation. A conceptual multidimensional schema is composed of facts and dimensions. Facts are composed of measures and dimensions are composed of hierarchies. Hierarchies are built upon rollup relationships between dimension levels. The roles of rollup relationships are characterized by their multiplicity. For example, when the lower multiplicity of the source role is 0 , we have an asymmetric hierarchy [10]; when the upper multiplicity of the target role is * (i.e. the target is plural), we have a non-strict hierarchy [10], which requires the definition of a coefficient [3]. The model enables the data warehouse designer to specify some applicable aggregation functions; however, this is not compulsory since PRR rules (described in Section 3) are specifically aimed at representing dynamic aggregation knowledge, including applicable aggregation functions.

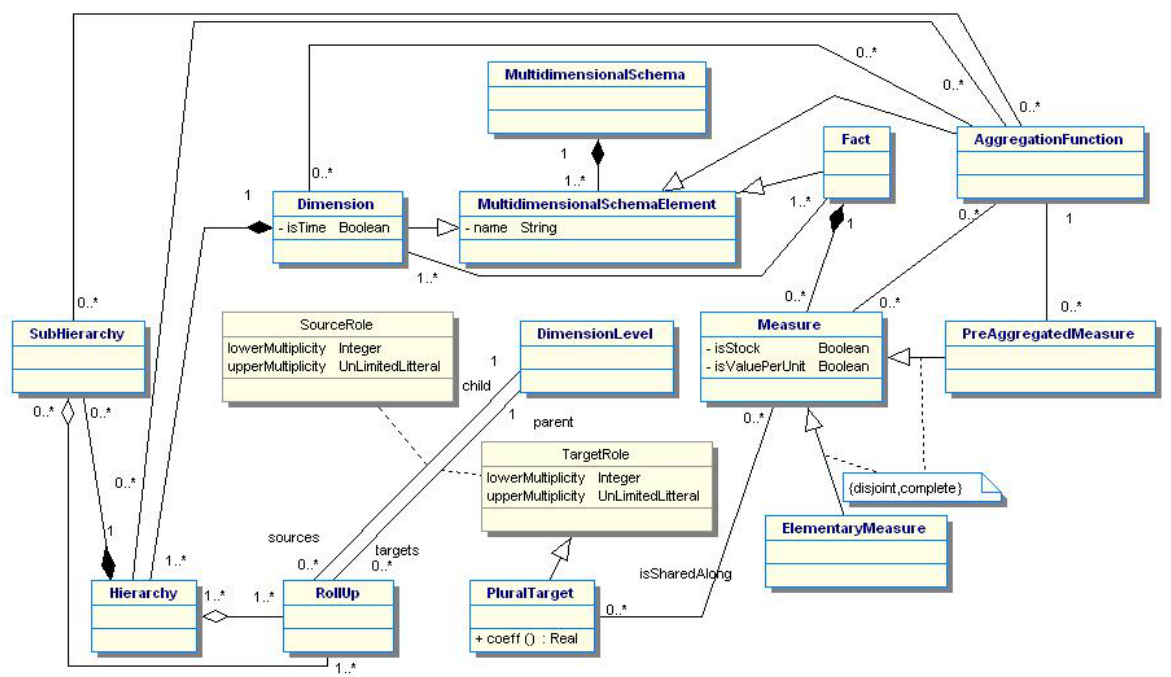

Fig. 1. Core Conceptual Multidimensional Model (MM): static view

Figure 2 represents the static view of a data cube ("MM" refers to classes of the core conceptual multidimensional model). A data cube is composed of cells and axes. Each axis has a default hierarchy (the default hierarchy used for rollup, as proposed in the Common Warehouse Metamodel [12]). A cell is composed of cell values (one value for each measure). Cell values may be base cell values or aggregated cell values (i.e. cell values resulting from previous rollups). 


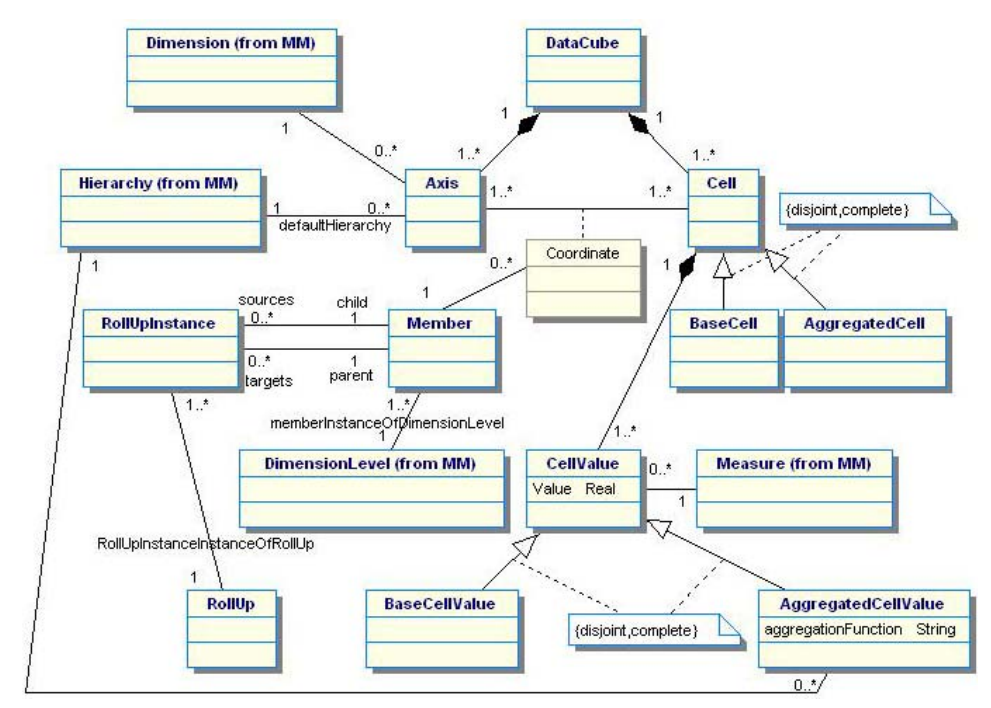

Fig. 2. Data cube model: static view

\section{Representing Dynamic Aggregation Knowledge: PRR Rules}

In order to completely represent aggregation knowledge, we must specify how, in a given context, aggregation may be performed on a given data cube (i.e. how to choose the aggregation function, and how to perform the aggregation once the aggregation function has been chosen). Since this knowledge is complex and highly contextual (depending on the data cube, the user preferences...), it is appropriately represented with rules. Rules also enable us to explain why a particular aggregation function has been chosen in a given context and how it has been applied.

To represent aggregation rules, we have chosen the Production Rule Representation language, complying with our choice of UML for representing the conceptual multidimensional model. The Production Rule Representation language enables the representation of rules related to the UML class diagrams presented in section 2, independently of subsequent implementations.

\subsection{The Production Rule Representation Language (PRR)}

The Production Rule Representation language (PRR) [12] has been proposed by OMG for high-level (tool-independent) representation of rules.

PPR rules are grouped into rulesets. A ruleset is a collection of rules with a particular mode of execution (sequential or inferencing). When inferencing is chosen 
as a mode of execution, priorities may be defined to constrain the order in which rules will be executed. PRR currently supports forward chaining only.

A production rule is typically represented as if [condition] then [action-list]. For example, an action may be the invocation of an operation associated with a class, or the assertion (creation) of a new object.

Variables may be defined at the ruleset level or the rule level. Rules variables are used for binding.

PRR rules can be represented formally, based on an extension of the Object Constraint Language (OCL) [12].

\subsection{Typology and Examples of Rules}

We distinguish the following types of aggregation rules:

- Semantic aggregation rules, which are based on the semantics of elements of the conceptual multidimensional model (e.g. semantics of dimensions, measures, aggregation functions).

- Syntactic aggregation rules, which express the mathematical properties of aggregation functions (e.g. commutativity, related to the concept of distributivity [8]).

- User preferences (e.g. "The aggregation function SUM should be used preferably to other aggregation functions.").

- Aggregation execution rules.

Semantic and syntactic aggregation rules indicate which aggregations are correct; user preferences indicate which aggregations are preferable (in case several candidate aggregation functions are applicable). Finally, aggregation execution rules indicate how a particular aggregation function should be executed once it has been chosen (e.g. how to perform aggregation along a non-strict [10] hierarchy).

We give illustrations for each category of rules.

\section{Semantic aggregation rules}

These rules are complex and may depend, among other things, on the semantics of measures, dimensions and hierarchies. By representing aggregation knowledge as rules, we enable easy update of semantic aggregation knowledge (new rules are added as new semantic aggregation knowledge is acquired). [7].

Example R1: Measures of type stock are not additive along temporal dimensions

Example R2: Ratios are not additive along any dimension [7].

Example R3: For a non-elementary (i.e. pre-aggregated) measure of type COUNT, along certain dimensions, aggregation may be incorrect from a certain dimension level, or a change in aggregation function may be necessary. 
As an illustration of rule R3, consider the number of credits of a module (i.e. the number of credits that the student will get in the module if he passes). Suppose we have the hierarchy module $\rightarrow$ diploma $\rightarrow$ institution. When rolling up from module to diploma, it makes sense to use the aggregation function SUM (total number of credits for the diploma). However, totaling the number of credits for the different diplomas of an institution does not make sense. Other aggregation functions may be used instead, e.g. MIN.

\section{Syntactic aggregation rules}

These rules indicate the correct sequencing of aggregation functions, within a given dimension (intra-dimension syntactic aggregation rules), or between different dimensions (inter-dimension syntactic aggregation rules, sometimes referred to as commutativity).

Example R4 (intra-dimension rule): For a given measure, for a given dimension, making the sum of averages does not make sense.

\section{User preferences}

These rules enable the representation of preferences for a given user, a profile of users, or for all users.

Example R5: If applicable aggregation functions are specified in the core conceptual multidimensional model, these functions should be applied in priority. [13].

Example R6: SUM should be applied preferably to all other aggregation functions

$$
\text { Example R7: AVG, MIN or MAX should be applied preferably to COUNT [13]. }
$$

Example R8: For a given measure, the same aggregation function should be applied to all dimensions along all hierarchies.

Example R9: For a given measure and a given hierarchy, the same aggregation function should be applied along all levels of the hierarchy.

Example R10: Aggregation should be stopped when null values are obtained. (Null values may be obtained when aggregating measures along asymmetric hierarchies [10] for example).

\section{Aggregation execution rules}

These rules are needed, in particular, to deal with non-standard (e.g. non-strict or asymmetric) hierarchies. They may also explicit how null values are taken into account in computing aggregation, which is crucial in OLAP applications [8]. 
Example R11: Sums along non-strict hierarchies are performed by consider null values as 0 .

\subsection{PRR rules organization and examples}

The context of aggregation consists in a triple <data cube, measure, axis>. Data cube is the active data cube, measure is the measure that the user wants to aggregate, and axis is the axis along which the user wants to perform the aggregation. We define a first ruleset for choosing the aggregation function. Inside the ruleset, the candidate aggregation functions are determined by means of the semantic and syntactic aggregation rules, and user preferences. These rules add or delete aggregation functions in the list of candidate aggregation functions. Ultimately, a unique aggregation function is chosen. (We illustrate a few examples of the rules described in section 3.2.)

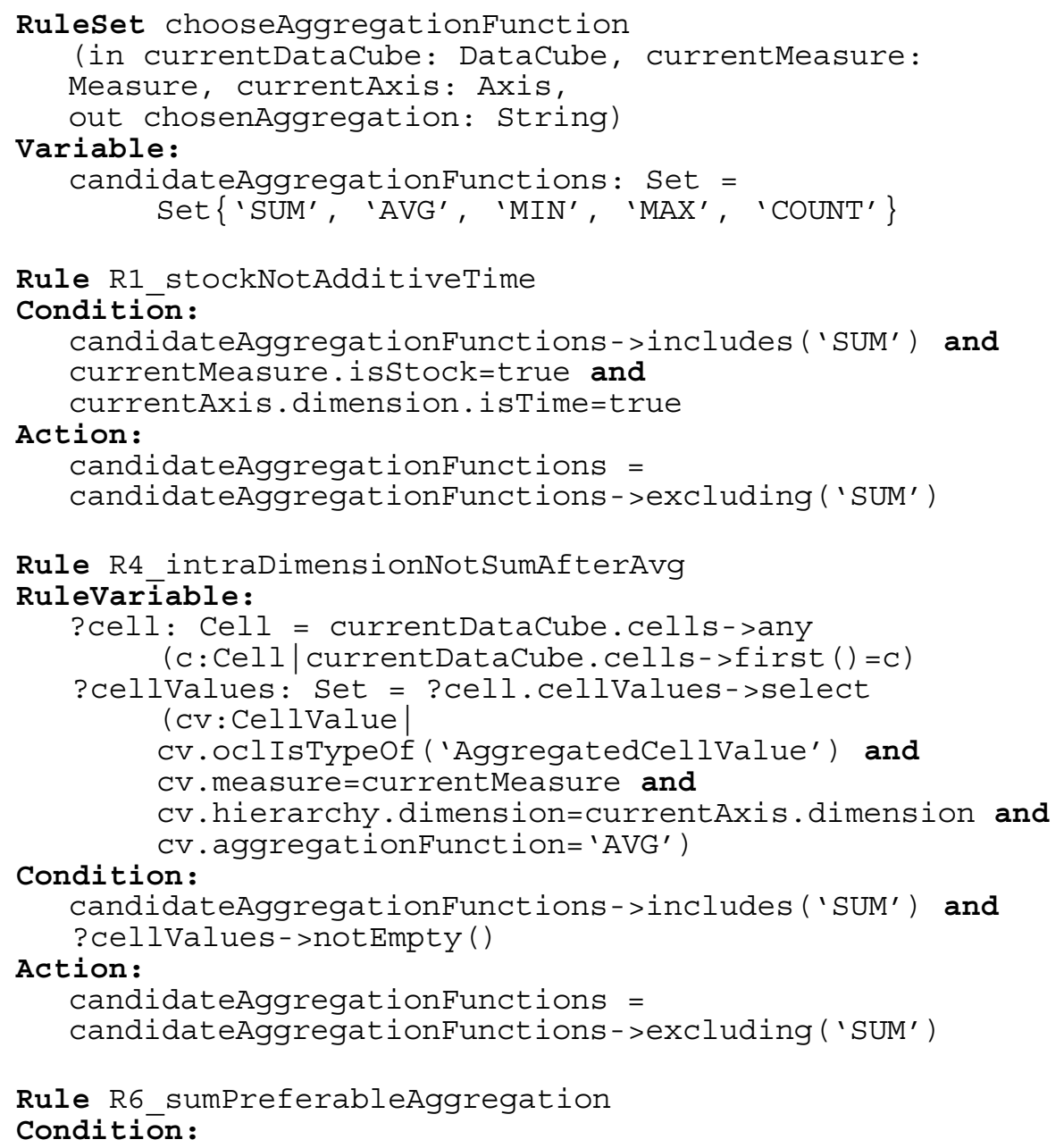




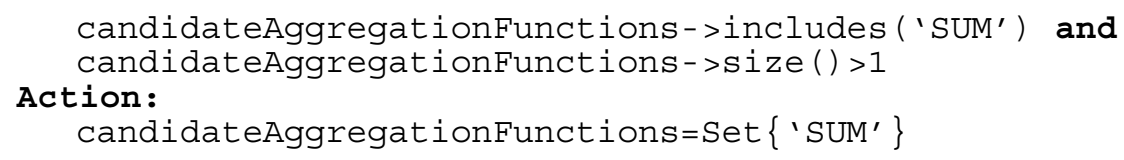

Once a unique aggregation function has been chosen, aggregation execution rules are used to perform the aggregation. For this purpose, we define a second ruleset. (In the sequel, we assume, for the sake of brevity, that there is only one measure, one axis, and no non-strict hierarchies). The first 3 rules are always executed, while the last rule implements rule 11 presented above.

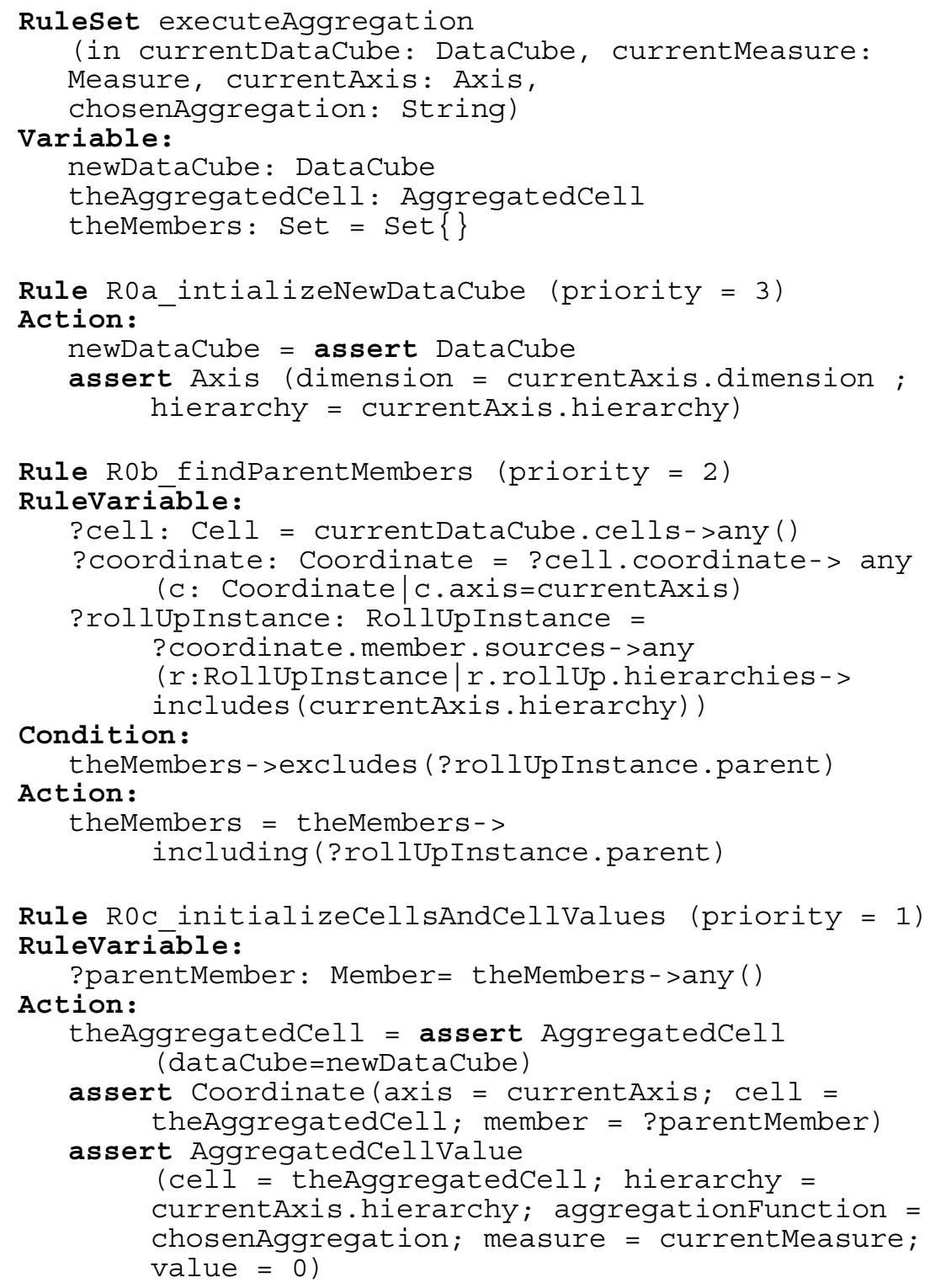




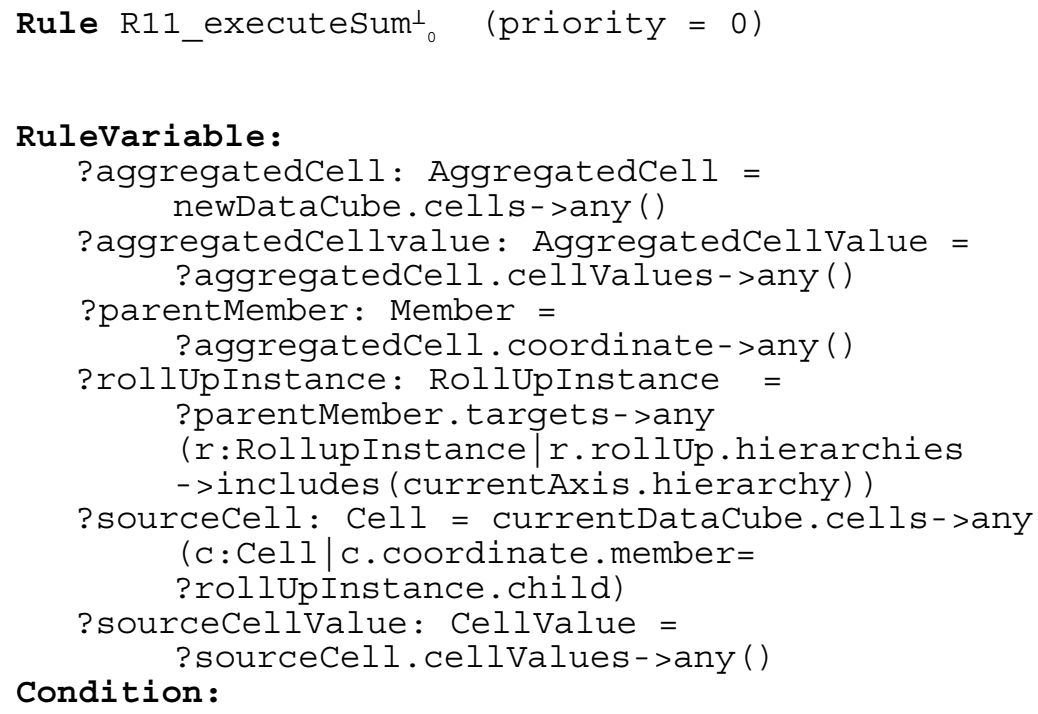

?sourceCellValue. value $<>\perp$

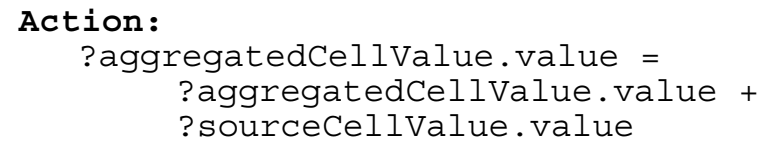

\section{Conclusion and Further Research}

The aggregation concept is of central concern in data warehouse design and multidimensional modeling. However, it is generally poorly represented, due to the fact that multidimensional models mainly focus on static knowledge representation. To overcome this limitation, we proposed in this paper to use Production Rule Representation to enrich UML class diagrams with dynamic aggregation knowledge. The literature mentions approaches which mainly represent information on aggregation hierarchies. We go beyond by proposing PRR as a means to incorporate dynamic aggregation knowledge in the multidimensional model. In order to achieve this objective, we extended PRR allowing us to define variables representing collection types as in standard OCL. The main contributions of this paper are in i) collecting knowledge on aggregation in the literature, ii) classifying it into semantic rules, syntactic rules, user-preference rules, and execution rules, iii) homogenizing the description of these rules in a unique formalism using PRR language, and iv) demonstrating the expressive power of PRR language. Beyond the examples of PRR 
rules as illustrated in this paper, we plan to perform larger experiments based on a prototype. The next step of our research will consist of the definition of mapping rules to transform PRR aggregation rules into commands that could be executed by an OLAP tool. The typology of aggregation rules can also be refined and used to define rule execution strategies. Finally, sequence diagrams could be used to combine rulesets, as proposed in [1].

\section{References}

1. Abdullah, M., Benest, I., Paige, R., Kimble, C.: Using Unified Modeling Language for conceptual modeling of Knowledge-Based Systems, Proc. ER 2007, Auckland, New Zealand, November 2007

2. Abello, A., Samos, J., Saltor, F.: YAM²: a multidimensional conceptual model extending UML, Information Systems, 31 (6), September 2006

3. Akoka, J., Comyn-Wattiau, I., Prat, N.: Dimension hierarchies design from UML generalizations and aggregations, Proc. ER 2001, Yokohama, Japan, November 2001

4. Espil, M.M., Vaisman, A.: Revising aggregation hierarchies in OLAP: a rule-based approach, Data \& Knowledge Engineering, 45 (2), May 2003

5. Horner, J., Song, I.-Y., Chen, P.: An analysis of additivity in OLAP systems, Proc. DOLAP'04, Washington, DC, USA, November 2004

6. Hüsemann, B., Lechtenbörger, J., Vossen, G.: Conceptual data warehouse design, Proc. DMDW 2000, Stockholm, Sweden, June 2000

7. Lenz, H.-J., Shoshani, A.: Summarizability in OLAP and statistical data bases, Proc. SSDBM’97, Olympia, Washington, USA, August 1997

8. Lenz, H.-J., Thalheim, B.: OLAP databases and aggregation functions, Proc. SSDBM 2001, Fairfax, Virginia, USA, July 2001

9. Lujan-Mora, S., Trujillo, J., Song, I.-Y.: A UML profile for multidimensional modeling in data warehouses, Data \& Knowledge Engineering, 59 (3), December 2006

10. Malinowski, E., Zimanyi, E.: Hierarchies in a multidimensional model: from conceptual modeling to logical representation, Data \& Knowledge Engineering, 59 (2), November 2006

11. March, S., Hevner, A.: Integrated decision support systems: a data warehousing perspective, Decision Support Systems, 43 (3), April 2007

12. Object Management Group: OMG specifications, available at http://www.omg.org/technology/documents/spec_summary.htm

13. Pedersen, T., Jensen, C.: Multidimensional data modeling for complex data, Proc. ICDE’99, Sydney, Australia, March 1999

14. Prat, N., Akoka, J., Comyn-Wattiau, I.: A UML-based data warehouse design method, Decision Support Systems, 42 (3), December 2006

15. Torlone, R.: Conceptual multidimensional models. In M. Rafanelli (ed), Multidimensional databases: problems and solutions, Idea Group, 2003 


\section{$\underline{\text { ESSEC }}$}

CENTRE

DE RECHERCHE

LISTE DES DOCUMENTS DE RECHERCHE DU CENTRE DE RECHERCHE DE L'ESSEC

(Pour se procurer ces documents, s'adresser au CENTRE DE RECHERCHE DE L'ESSEC)

LISTE OF ESSEC RESEARCH CENTER WORKING PAPERS

(Contact the ESSEC RESEARCH CENTER for information on how to obtain copies of these papers)

RESEARCH.CENTER@ESSEC.FR

2004

04001 BESANCENOT Damien, VRANCEANU Radu

Excessive Liability Dollarization in a Simple Signaling Model

04002 ALFANDARI Laurent

Choice Rules Size Constraints for Multiple Criteria Decision Making

04003 BOURGUIGNON Annick, JENKINS Alan

Management Accounting Change and the Construction of Coherence in Organisations: a Case Study

04004 CHARLETY Patricia, FAGART Marie-Cécile, SOUAM Saïd

Real Market Concentration through Partial Acquisitions

04005 CHOFFRAY Jean-Marie

La révolution Internet

04006 BARONI Michel, BARTHELEMY Fabrice, MOKRANE Mahdi

The Paris Residential Market: Driving Factors and Market Behaviour 1973-2001

04007 BARONI Michel, BARTHELEMY Fabrice, MOKRANE Mahdi

Physical Real Estate: A Paris Repeat Sales Residential Index

04008 BESANCENOT Damien, VRANCEANU Radu

The Information Limit to Honest Managerial Behavior

04009 BIZET Bernard

Public Property Privatization in France

04010 BIZET Bernard

Real Estate Taxation and Local Tax Policies in France

04011 CONTENSOU François

Legal Profit-Sharing: Shifting the Tax Burden in a Dual Economy

04012 CHAU Minh, CONTENSOU François

Profit-Sharing as Tax Saving and Incentive Device

04013 REZZOUK Med

Cartels globaux, riposte américaine. L'ère Empagran?

2005

05001 VRANCEANU Radu

The Ethical Dimension of Economic Choices

05002 BARONI Michel, BARTHELEMY Fabrice, MOKRANE Mahdi

A PCA Factor Repeat Sales Index (1973-2001) to Forecast Apartment Prices in Paris (France) 
Performance Appraisal Research: A Critical Review of Work on "the Social Context and Politics of Appraisal"

05005 BESANCENOT Damien, VRANCEANU Radu

Socially Efficient Managerial Dishonesty

05006 BOARI Mircea

Biology \& Political Science. Foundational Issues of Political Biology

05007 BIBARD Laurent

Biologie et politique

05008 BESANCENOT Damien, VRANCEANU Radu

Le financement public du secteur de la défense, une source d'inefficacité ?

\section{6}

06001 CAZAVAN-JENY Anne, JEANJEAN Thomas

Levels of Voluntary Disclosure in IPO prospectuses: An Empirical Analysis

06002 BARONI Michel, BARTHELEMY Fabrice, MOKRANE Mahdi Monte Carlo Simulations versus DCF in Real Estate Portfolio Valuation

06003 BESANCENOT Damien, VRANCEANU Radu

Can Incentives for Research Harm Research? A Business Schools Tale

06004 FOURÇANS André, VRANCEANU Radu

Is the ECB so Special? A Qualitative and Quantitative Analysis

06005 NAIDITCH Claire, VRANCEANU Radu

Transferts des migrants et offre de travail dans un modèle de signalisation

06006 MOTTIS Nicolas

Bologna: Far from a Model, Just a Process for a While...

06007 LAMBERT Brice

Ambiance Factors, Emotions and Web User Behavior: A Model Integrating and Affective and Symbolical Approach

06008 BATISTA Catia, POTIN Jacques

Stages of Diversification and Capital Accumulation in an Heckscher-Ohlin World, 1975-1995

06009 TARONDEAU Jean-Claude

Strategy and Organization Improving Organizational Learning

06010 TIXIER Daniel

Teaching Management of Market Driven Business Units Using Internet Based Business Games

06011 COEURDACIER Nicolas

Do Trade Costs in Goods Market Lead to Home Bias in Equities?

06012 AVIAT Antonin, COEURDACIER Nicolas

The Geography of Trade in Goods and Asset Holdings

06013 COEURDACIER Nicolas, GUIBAUD Stéphane International Portfolio Diversification Is Better Than You Think

06014 COEURDACIER Nicolas, GUIBAUD Stéphane

A Dynamic Equilibrium Model of Imperfectly Integrated Financial Markets

06015 DUAN Jin-Chuan, FULOP Andras

Estimating the Structural Credit Risk Model When Equity Prices Are Contaminated by Trading Noises

06016 FULOP Andras

Feedback Effects of Rating Downgrades 
06017 LESCOURRET Laurence, ROBERT Christian Y.

Preferencing, Internalization and Inventory Position

06018 BOURGUIGNON Annick, SAULPIC Olivier, ZARLOWSKI Philippe

Management Accounting Change in the Public Sector: A French Case Study and a New Institutionalist Perspective

06019 de BEAUFORT Viviane

One Share - One Vote, le nouveau Saint Graal ?

06020 COEURDACIER Nicolas, MARTIN Philippe

The Geography of Asset Trade and the Euro: Insiders and Outsiders

06021 BESANCENOT Damien, HUYNH Kim, VRANCEANU Radu

The "Read or Write" Dilemma in Academic Production: A European Perspective

2007

07001 NAIDITCH Claire, VRANCEANU Radu

International Remittances and Residents' Labour Supply in a Signaling Model

07002 VIENS G., LEVESQUE K., CHAHWAKILIAN P., EL HASNAOUI A., GAUDILLAT A., NICOL G., CROUZIER C.

Évolution comparée de la consommation de médicaments dans 5 pays européens entre 2000 et 2004 : analyse de 7 classes pharmaco-thérapeutiques

07003 de BEAUFORT Viviane

La création d'entreprise au féminin dans le monde occidental

07004 BOARI Mircea

Rationalizing the Irrational. The Principle of Relative Maximization from Sociobiology to Economics and Its Implications for Ethics

07005 BIBARD Laurent

Sexualités et mondialisation

07006 VRANCEANU Radu

The Moral Layer of Contemporary Economics: A Virtue Ethics Perspective

07007 LORINO Philippe

Stylistic Creativity in the Utilization of Management Tools

07008 BARONI Michel, BARTHELEMY Fabrice, MOKRANE Mahdi

Optimal Holding Period for a Real Estate Portfolio

07009 de BEAUFORT Viviane

One Share - One Vote, the New Holy Graal?

07010 DEMEESTERE René

L'analyse des coûts : public ou privé ?

07011 TIXIER Maud

Appreciation of the Sustainability of the Tourism Industry in Cyprus

07012 LORINO Philippe

Competence-based Competence Management: a Pragmatic and Interpretive Approach. The Case of a Telecommunications Company

07013 LORINO Philippe

Process Based Management and the Central Role of Dialogical Collective Activity in Organizational Learning. The Case of Work Safety in the Building Industry

07014 LORINO Philippe

The Instrumental Genesis of Collective Activity. The Case of an ERP Implementation in a Large Electricity Producer

07015 LORINO Philippe, GEHRKE Ingmar

Coupling Performance Measurement and Collective Activity: The Semiotic Function of Management Systems. A Case Study 
The Classroom as a Potential Space - Teaching Negotiation through Paradox

07019 ESPOSITO VINZI Vincenzo

Capturing and Treating Unobserved Heterogeneity by Response Based Segmentation in PLS Path Modeling. A Comparison of Alternative Methods by Computational Experiments

07020 CHEVILLON Guillaume, Christine RIFFLART

Physical Market Determinants of the Price of Crude Oil and the Market Premium

07021 CHEVILLON Guillaume

Inference in the Presence of Stochastic and Deterministic Trends

07023 COLSON Aurélien

The Ambassador, between Light and Shade. The Emergence of Secrecy as the Norm of International Negotiation

07024 GOMEZ Marie-Léandre

A Bourdieusian Perspective on Strategizing

07025 BESANCENOT Damien, VRANCEANU Radu

Multiple Equilibria in a Firing Game with Impartial Justice

07026 BARONI Michel, BARTHELEMY Fabrice, MOKRANE Madhi

Is It Possible to Construct Derivatives for the Paris Residential Market?

08001 BATISTA Catia, POTIN Jacques

International Specialization and the Return to Capital, 1976-2000

08002 BESANCENOT Damien, FARIA Joan Ricardo, VRANCEANU Radu

Why Business Schools Do So Much Research: a Signaling Explanation

08003 de BEAUFORT Viviane

D'un effet vertueux de l'art. 116 de la loi NRE en matière de RSE ? La problématique est posée à échelle de l'Union européenne

08004 MATHE Hervé

Greater Space Means More Service: Leveraging the Innovative Power of Architecture and Design

08005 MATHE Hervé

Leading in Service Innovation: Three perspectives on Service Value delivery in a European Context

08006 ROMANIUK Katarzyna, VRANCEANU Radu

Asset Prices and Asymmetries in the Fed's Interest Rate Rule: A Financial Approach

08007 MOTTIS Nicolas, WALTON Peter

Measuring Research Output across Borders - A Comment

08008 NAPPI-CHOULET Ingrid, MAURY Tristan-Pierre

A Spatiotemporal Autoregressive Price Index for the Paris Office Property Market

08009 METIU Anca, OBODARU Otilia

Women's Professional Identity Formation in the Free/Open Source Software Community

08010 SIBIEUDE Thierry, VIDAL Rodolphe

Le programme « Une grande école : pourquoi pas moi ? $₫$ ». D'une action de responsabilité sociétale de I'ESSEC à la responsabilité sociétale des grandes écoles françaises

08011 SIBIEUDE Thierry, VIDAL Rodolphe

Enjeux et perspectives du sociétariat des groupes mutualistes complexes face aux stratégies de développement à l'échelle groupe : quelques enseignements du cas du groupeMACIF 
08013 CAZAVAN-JENY Anne, JEANJEAN Thomas

Supply and Demand for European Accounting Research. Evidence from EAA Congresses

08014 FAYARD Anne-Laure, METIU Anca

Beyond Orality and Literacy: Letters and Organizational Communication

08015 CAZAVAN-JENY Anne, MISSONIER-PIERA Franck, MARGAINE J.

CEO Compensations in a Stakeholders' Regime: An Empirical Investigation with French Listed Companies

08016 METIU Anca, FAYARD Anne-Laure

Letters and Scientific Communities

08017 BESANCENOT Damien, VRANCEANU Radu

Migratory Policy in Developing Countries: How to Bring Best People Back?

08018 BESANCENOT Damien, VRANCEANU Radu

Financial Distress and Bank's Communication Policy in Crisis Time

08019 AGID Philippe, TARONDEAU Jean-Claude

Les performances des maisons d'Opéra : une explication statistique

2009

09001 POTIN Jacques

The Selection Effect of Two-way Trade in the Melitz Model: An Alternative Approach

09002 NAIDITCH Claire, VRANCEANU Radu

Migratory Equilibria with Invested Remittances

09003 BARONI Michel, BARTHELEMY Fabrice, MOKRANE Mahdi

A Repeat Sales Index Robust to Small Datasets

09004 NAPPI-CHOULET Ingrid, MAURY Tristan-Pierre

A Spatial and Temporal Autoregressive Local Estimation for the Paris Housing Market

09005 BENCHIMOL Jonathan, FOURÇANS André

Money in a DSGE Framework with an Application to the Euro Zone

09006 VRANCEANU Radu

Four Myths and a Financial Crisis

09007 BESANCENOT Damien, VRANCEANU Radu

Banks' Risk Race: A Signaling Explanation

09008 BESANCENOT Damien, HUYNH Kim, VRANCEANU Radu

Desk Rejection in an Academic Publication Market Model with Matching Frictions

09009 BOUTY Isabelle, GOMEZ Marie-Léandre

Unpacking Knowing Integration: A Practice-based Study in Haute Cuisine

09010 GOMEZ Marie-Léandre, BOUTY Isabelle

The Social Dimensions of Idea Work in Haute Cuisine: A Bourdieusian Perspective

09011 GOMEZ Marie-Léandre

Knowledge Dynamics During Planning Practices

09012 GIRAUD Gaël, RENOUARD Cécile

Relational Capability: An Indicator of Collective Empowerment

09013 MOTTIS Nicolas, PONSSARD Jean-Pierre

Création de valeur, 10 ans après... 
Pour tous renseignements :

- Centre de Recherche/Research Center Tél. 33 (0)1 34433091

research.center@essec.fr

- Visitez notre site

www.essec.fr

ESSEC BUSINESS SCHOOL PARIS

AVENUE BERNARD HIRSCH - BP 50105 CERGY

95021 CERGY-PONTOISE CEDEX - FRANCE

TÉL. +33 (0)134433000 - FAX +33 (0)134433001

www.essec.fr

ESSEC EXECUTIVE EDUCATION

CNIT - BP 230

92053 PARIS LA DÉFENSE - FRANCE

TÉL. +33 (0)146924900 - FAX +33 (0)146924990

http://formation.essec.fr

ESSEC BUSINESS SCHOOL, SINGAPORE CAMPUS

100 VICTORIA STREET - NATIONAL LIBRARY BUILDING \#13-02

SINGAPORE 188064

TÉL. +65 68849780 - FAX +65 68849781

www.essec.edu

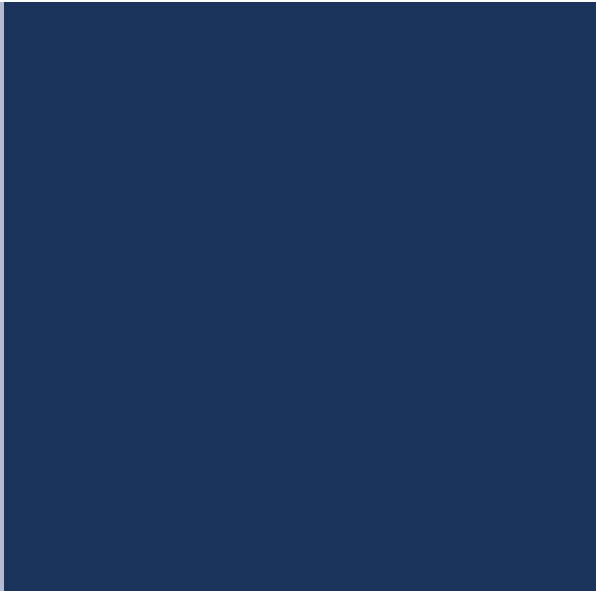

